40th Anniversary

\title{
レーザー核融合研究の進展
}

\author{
白神 宏之, 疇地 宏 \\ 大阪大学レーザーエネルギー学研究センター（†565-0871 大阪府吹田市山田丘2-6）
}

\section{Progress of Laser Fusion Rersearch}

Hiroyuki SHIRAGA and Hiroshi AZECHI

Institute of Laser Engineering, Osaka University, 2-6 Yamada-Oka Suita, Osaka 565-0871

(Received Received February 28, 2013)

\begin{abstract}
Laser-driven inertial confinement fusion (laser fusion) has been investigated with large-scale high-power lasers since 1960's. Progress of new laser technology, such as multi-beam irradiation system, frequency conversion, beam smoothing, and chirped pulse amplification, significantly accelerated the laser fusion research. FIREX project to demonstrate efficient heating of the compressed fuel to the ignition temperature with Fast Ignition scheme is underway in Osaka. Attempt to achieve high-density implosion and ignition is also underway on NIF in the US, and the first demonstration of the thermo nuclear ignition and burning of controlled nuclear fusion will be demonstrated soon by laser fusion. Laser fusion demo power plants are expected to appear in 2020-2030. Laser drivers with large output energy, high efficiency, high repetition rate, long life, and low cost will be required for laser fusion reactors.
\end{abstract}

Key Words: Inertial confinement fusion, High-power laser, Implosion, Fast ignition, Thermo nuclear ignition

1.はじめに

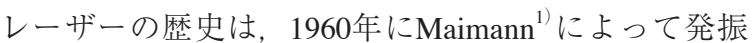
が成功して以来既に50年を超え, その技術的発展には驚 嘆すべきものがある，典型的な大出力パルスレーザーの ひとつである大型のガラスレーザーは, 主としてレー ザー核融合研究の要請により開発・建設が進められてき た経緯がある。レーザー出力の増強とともにレーザー核 融合研究は進展してきた。 しかしその過程は決して大出 力化だけではなく, レーザー核融合プラズマ物理からの 要請によりさまざまな高精度レーザー技術が開発導入さ れ，また逆に新しいレーザー技術が核融合研究を加速し てきたと言える。本稿では，レーザー核融合研究の進展 の経緯についてこれまであちこちに報告してきた内容を まとめつつ，現状と将来展望を述べてみたい．

2.レーザーを用いた核融合の原理と エネルギードライバー

磁場閉じ込め核融合では，密度は $10^{15} \mathrm{~cm}^{-3}$ 程度(室温1 気圧気体の $10^{-5}$ 倍程度) と低いが, 磁場によりプラズマ を閉じ込めて反応時間を長く取ることで反応数を確保す
るのに対し，レーザーなどを用いた慣性核融合では密度 を $10^{26} \mathrm{~cm}^{-3}$ 程度 (固体密度の1000倍程度) と極端に高くし 時間は短くとも衝突頻度を上げて反応数を稼ぐ，超高 温・超高密度すなわち超高圧力状態になった燃料プラズ マは短時間に熱的に膨張・飛散するが，飛散するまでの 慣性で留まっている間だけ反応は続く。

超高密度状態を作る手法として，レーザーなど超高パ ワー密度のエネルギードライバーを用いた「爆縮 (implosion)」という概念を用いる，爆縮とは，照射する レーザーの光エネルギーを，プラズマの熱エネルギーー 膨張反作用(アブレーション)による燃料プラズマの運動 エネルギー 一燃料の圧縮仕事 $\rightarrow$ 燃料の熱エネルギー，と エネルギー変換し，時間空間的にパルス圧縮して高密度 圧縮を行う，流体力学的手法である。爆縮こそはレー ザー核融合の根幹をなす概念であり，爆縮プラズマとは その様なエネルギー変換デバイスであると考えることが 出来る。

慣性核融合におけるもう一つの重要な概念は「自己点 火」である。圧縮する燃料を冷たいまま保てるなら燃料 に与えるエネルギーはFermiエネルギーのみで小さくて 済む。その上で，燃料の一部のみを核融合点火させれ ば，点火部分から発生した核反応粒子が周辺部を過熱し 
燃焼波伝搬により全体が燃え広がる。自己点火するため には点火部の燃料の密度 - 半径積 $(\rho R)$ が, 例えばDT燃 料なら発生するアルファ粒子の飛程 $\left(0.3 \mathrm{~g} / \mathrm{cm}^{2}\right)$ より大き いことが条件となる。

レーザーによる爆縮の概念は1972年になって初めて公 表された ${ }^{3)}$ 。これは主燃料を個体密度の1000倍程度に圧 縮し，その中心部に $5 \mathrm{keV}$ 以上の中心点火スパークを形 成するというシナリオであり，レーザー核融合の具体的 設計提案であった。この実現を目指して1970年代後半か ら1980年代前半にかけて米国，日本，ヨーロッパにおい て大型レーザーが建設され, 爆縮核融合の本格的研究が スタートした。

なお，慣性核融合ドライバーとしては，ガラスレー ザーのみならず炭酸ガスレーザー, KrFレーザー, 相対 論的電子ビーム, 軽イオンビーム, 重イオンビーム等も 検討されたが, 電子輸送や装置の制御性の観点から, 実 験用にはガラスレーザーが最も適していたと言える。し かし発電炉用には高効率と高繰り返しの観点からガラス レーザーではなく, 後述の新しいレーザーが求められ る。その観点から, KrFレーザー, 重イオンビームにつ いては現在も研究が続けられている.

\section{3. 爆縮核融合研究の進展と} レーザー技術のもたらしたもの

爆縮核融合研究の進展においてレーザー技術の展開が どのように作用したかを，研究開発の流れとして時間的 に振り返って見てみたい。興味深いことに，プラズマ物 理の問題を解決するために新しいレーザー技術が要請さ れ，又逆に新しいレーザー技術が導入されることでレー ザー核融合研究に新しい進展がもたらされてきた。

\section{1 多ビーム高出力装置の建設と本格的爆縮実験の} 開始

爆縮核融合では球状の燃料ターゲットを均一に照射し 圧縮するので，1980年代前半から米・日・欧で建設され た本格的レーザー装置はいずれも必然的に球対称照射系 あるいはそれに準ずる多ビームのシステムであり，これ により本格的爆縮実験が行われるようになった。しかし 後述するように，照射の球対称性あるいは一様性に対す る要請はこの段階で考えられていたよりも遙かに厳しい ものであることが，その後間もなく明らかとなる。その 結果, 1990年代後半に改造された米国ロチェスター大学 のOMEGA-UG装置は60ビーム，その後米国リバモア研 で建設されたNIF(National Ignition Facility) 装置は192 ビームという, 極めて多ビームの装置となった。

3.2 レーザー光の高調波変換とLHARTターゲットに よる高温度爆縮

高出力と制御性の観点からほとんどの爆縮用レーザー 装置はガラスレーザーであった。 しかし，その基本波で ある $1.05 \mu \mathrm{m}$ 光では, プラズマ中で発生する高速電子 ${ }^{4)}$ が 多すぎて圧縮する前に燃料の温度が上がってしまうプレ
ヒートと呼ばれる問題があり，またアブレーションによ る駆動圧力が低い。これらを解決するためにより短波長 のレーザー光が求められた。これに応えて, 主として $\mathrm{KDP}$ 等の非線形光学結晶を用いた波長変換技術が開発さ れ，照射レーザーは2倍高調波 $(0.53 \mu \mathrm{m})$ や3倍高調波 $(0.35 \mu \mathrm{m})$ に短波長化された (Fig. 1).

波長変換技術そのものは以前から知られていたが，大 口径, 高フルーエンスでの高効率変換には，数 $10 \mathrm{~cm}$ m級の大型の結晶育成や高精度光学素子としての研磨技 術など，多くの困難があった。この高調波発生技術によ りプレヒートが少なく効率の高いアブレーション駆動に よる爆縮が可能となった。

核融合点火に必要な5-10 keVを実現することは, 1985 - 1986年に大阪大学の激光XII号ガラスレーザー(波 長 $0.53 \mu \mathrm{m}$, 光出力 $15 \mathrm{~kJ} / 12$ ビーム) (Fig. 2)により達成さ れた5)。これはLHART(Large High Aspect Ratio Target) と 呼ばれる, 直径 $1000 \mu \mathrm{m}$, 厚さ $1 \mu \mathrm{m}$ 程度の薄いガラスマ イクロバルーンにDTガスを封入したターゲットを用い, 多重衝撃波を爆縮コア形成時にターゲット中心に集中さ せるという方法で，このときDT核融合中性子 $10^{12}-10^{13}$ 個/ショット（核融合利得 $=0.2 \%)$ が発生した。 LHARTは シェルを徐々にアブレーティブ加速するが，シェルが薄 いので容易に高速度爆縮になり，高い温度が得られる。

LHARTにより, 多重衝撃波を使って流体力学的に然料

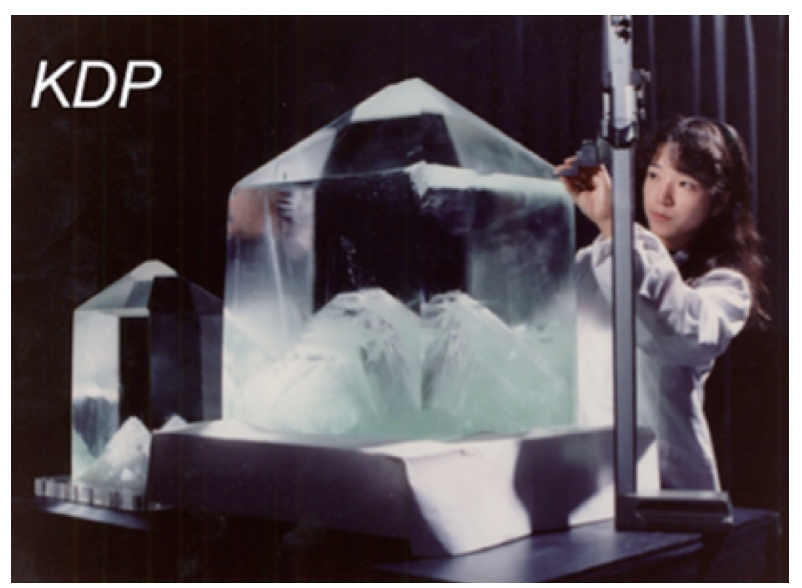

(a)

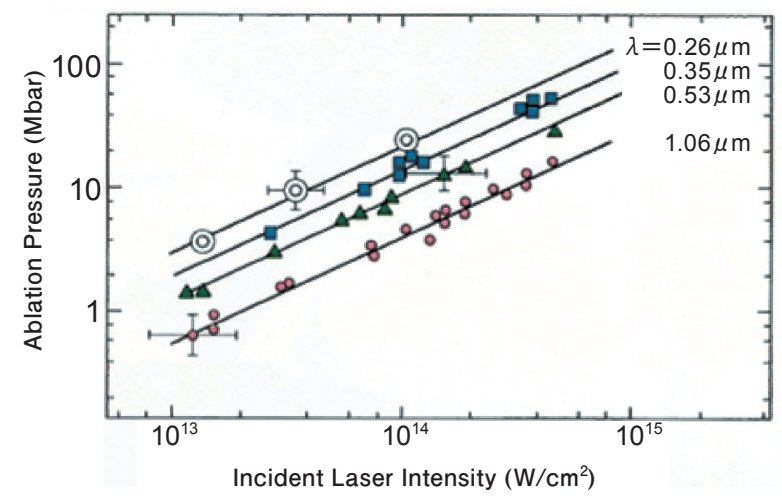

(b)

Fig. 1 (a) Large KDP crystals, (b) Laser-wavelength dependence of ablation pressure driven by laserirradiation. 


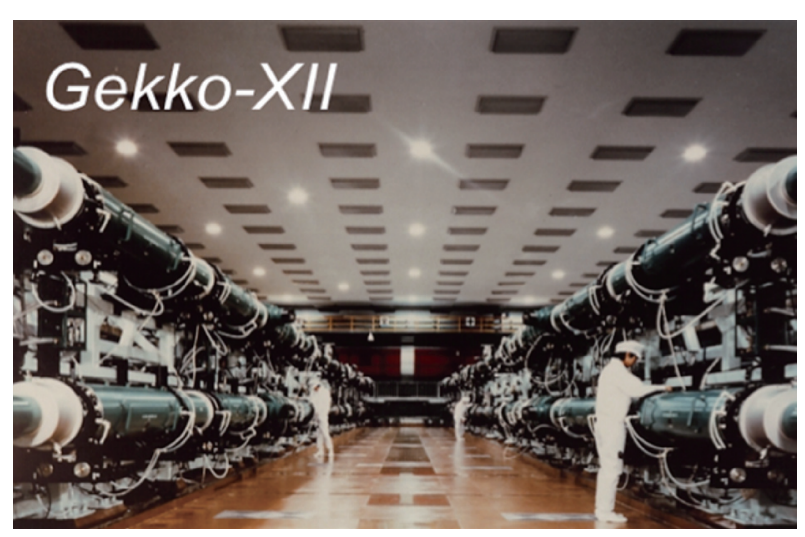

(a)

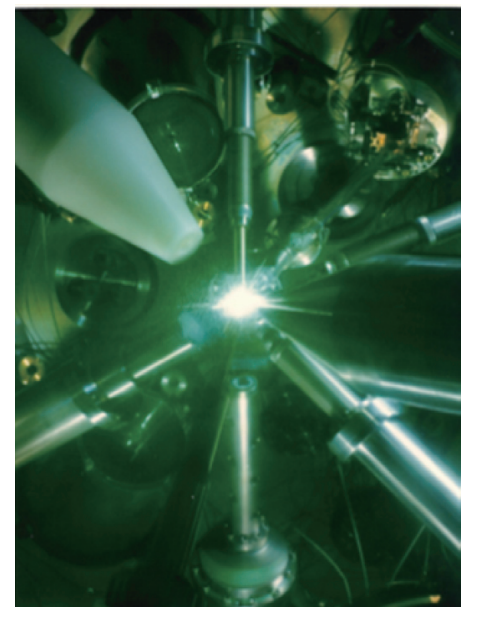

(b)

Fig. 2 Gekko-XII Nd:glass laser system. (a) Main amplifier chains, (b) Interior of the target chamber at the laser shot.

を加熱することを実証できた，ただし実験で成功したの はシェルがほとんど減速相を持たない，すなわち減速に 入る前に衝撃波集中が終わる場合のみである，減速相が 顕著な場合には，温度は上がっておらず，その原因は減 速時のシェル/燃料界面での流体不安定性により界面が 歪み, 往復する衝撃波による断熱圧縮が維持できなかっ たと考えられている6 .

\section{3 照射一様性向上と高密度爆縮}

主燃料を高密度に圧縮する試みは，1980年代後半に本 格化した，大阪大学の激光XII号レーザー(波長 $0.53 \mu \mathrm{m}$, 光出力 $8 \mathrm{~kJ} / 12$ ビーム) で重水素化ポリエチレンシェルを 爆縮し, 固体密度の600 1000倍クラスの圧縮が実証さ れた7).この場合のターゲットは直径 $500 \mu \mathrm{m}$, 殼厚 $8 \mu \mathrm{m}$ と厚いシェルで, 完全にアブレーティブな爆縮であっ た。この成果は, 真球度と殼厚一様性が $99 \%$ 以上の高品 質シェルターゲット，ランダム位相板 ${ }^{8}$ により照射一様 性を向上したレーザービームの使用 (Fig. 3) 㧍よび放射 化法による高精度プラズマ診断など，新たな技術の導入 によるものである。この結果により, 燃料の超高密度圧 縮も流体力学的に可能であることが実証された，ランダ ム位相板とは, ビームの開口を細かくセグメント化しラ ンダムに選んだセグメントに半波長の位相差をもたらす

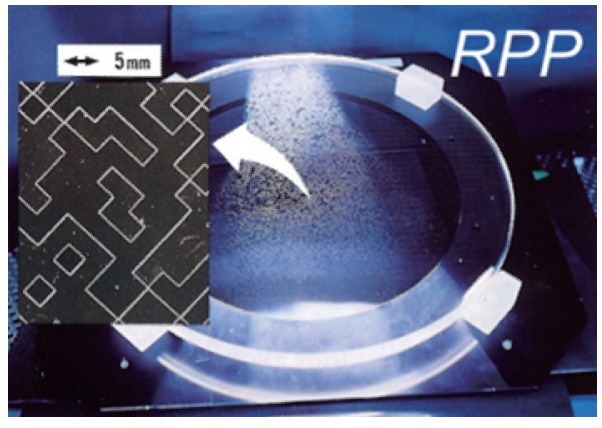

(a)
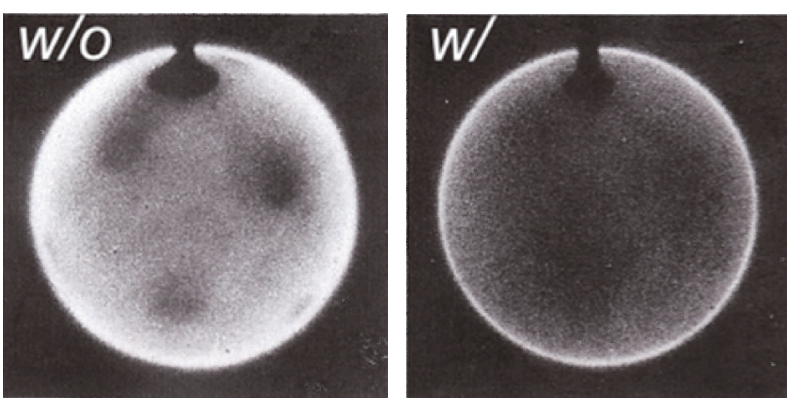

(b)

Fig. 3 (a) Pandom phase plate (RPP), (b) X-ray emission patterns of laser-irradiated spherical targets with (right) and without (left) RPP.

コーティングを施すものである。これはビームの空間コ ヒーレンスを破壊し焦点位置で混合し近視野像内の空間 分布を焦点面で均一化することが出来るデバイスであ り，「レーザーはコヒーレント」という概念を覆す技術で あった。

この実験で得られた $\rho R=0.5 \mathrm{~g} / \mathrm{cm}^{2}$, 密度 $600 \mathrm{~g} / \mathrm{cm}^{3}$ は, 1次元球対称シミュレーションの予測值と一致した。 つ まり，設計通りの高密度爆縮がなされたことになる。 ころが，このときの中性子イールドは予測から1〜3桁低 い值であった。すなわち, 主燃料爆縮は成功したが, 中 心ホットスパーク形成には失敗したと解釈された9?. そ の理由は，依然として懪縮一様性が不十分であるためと 考えられた

なお，この高密度爆縮の成果に関して米国は直ちに調 查団を大阪大学に派遣し詳細に実験結果をサーベイした が，それは結果的に米国に扔ける次のNIF計画の検討を 開始することに結びついた。

\section{4 高度なビーム平滑化と流体等価爆縮}

上記までの結果，レーザー核融合に必要な高温・高密 度はそれぞれ個別には達成されたが, 同時達成ではな い.これより, 爆縮非一様性がもっとも重要な問題であ ると認識され，これをいかに克服するかが最重要の物理 的・工学的課題となった。これ以後のレーザー装置建設 では, OMEGAやNIFのように, 多ビーム化によって照 射一様性を確保する試みがなされると同時に，レーザー 光の照射パターン自体を向上するため, ランダム位相板 からさらに飛躍して, スペクトル制御による均一化 ${ }^{10}$, 部分コヒーレント光 ${ }^{11}$ など, レーザー光のコヒーレンス 
制御技術が駆使された

1990年代には次の研究ステップとしてそのような均一 照射技術を用いて，「流体等価プラズマ」の実現が課題と なった。これは, 規模が小さいことを除いて密度, 半径 収縮率などの流体力学的パラメータが点火燃焼プラズマ と同等の高密度主燃料中に高温中心スパークを形成する もので，点火燃焼達成に必要とされるものと同等のレー ザー, ターゲット，および爆縮の品質が要求される。米 国では1994年にリバモア研のNOVAレーザーにおいて間 接照射によりこれを達成したと発表し，NIF建設へのス テップとした ${ }^{12)}$ 、ロチェスター大学OMEGAレーザーで は, 直接照射クライオ重水素燃料ターゲットを用いて現 在精力的に実験が進められ，低アイセントロープ $(\alpha \sim$ 4), 半径収縮率〜20で, 主燃料 $\rho R \sim 0.3 \mathrm{~g} / \mathrm{cm}^{2}$ のホット スパーク/主燃料構造を実現した ${ }^{13)}$ 。

\section{5 多様な基礎実験装置と高エネルギー密度科学の} 展開

高強度レーザーにより生成されるプラズマは, 超高 温・超高密度の物質であり, 高エネルギー密度物理学と しての研究展開が期待される。例えば, 天体現象の一部 をある程度実験室で模擬できることから，実験室宇宙物 理学や実験室惑星科学という分野が拓かれつつある。ま た超高温ではない場合にWarm Dense Matterという新し い研究が進められている。さらにはプラズマをX線や EUV光, 高エネルギー電子やイオンなどの放射光源と する応用研究も展開している。これらの基礎科学や応用 においては，必ずしも球対称の爆縮用レーザーではな く，平板ターゲットを様々な照射条件で実験出来るため の照射配位の方が有利である。大阪大学では，爆縮の基 礎過程の研究や様々な高エネルギー密度状態の物理研究 を目的として，激光XII号レーザーのフロントエンド部 および第2照射チェンバー室を全面改造し, 全ビームを束 ねて高強度で一方向から多様な条件で照射出来る装置HIPER とした(Fig.4). “HIPER”はHigh-Intensity Plasma Experimental Researchの略で，基礎実験に特化した照射系である。こ れは出力光のレーザー波長 $(1.05 \mu \mathrm{m}, 0.53 \mu \mathrm{m}, 0.35 \mu \mathrm{m})$, ビーム平滑化 (コヒーレント光, 部分コヒーレント光, $\mathrm{SSD}$ 光), パルス波形(100 ps〜20 ns) などを選択あるい は混合して実験に供給することが出来る，世界でもユ ニーク装置となっており, 幅広い分野の多くのユーザー に共同利用・共同研究の場を提供している.

例えば，爆縮過程における流体力学的不安定性，なか でもレイリー・テーラー (RT) 不安定性 ${ }^{14)}$ は, 加速相, 減速相いずれにおいても爆縮を阻害する最も大きな要因 であり，その物理と制御はレーザー核融合にとって極め て重要な研究課題である。大阪大学では, このHIPER装 置を駆使してRT不安定性の研究を精力的に行った ${ }^{15)}$. 特に, RT不安定性の成長率を記述する高部-Bodner公 式 ${ }^{16)}$ に現れる全てのパラメータを実験的に計測し, 式中 唯一の任意パラメータである $\beta$ 值を実験的に決定するこ とに成功し ${ }^{17)}$ ，それまで理論的に予想された值よりさら に安定化する擾乱の波長領域があることを見いだし

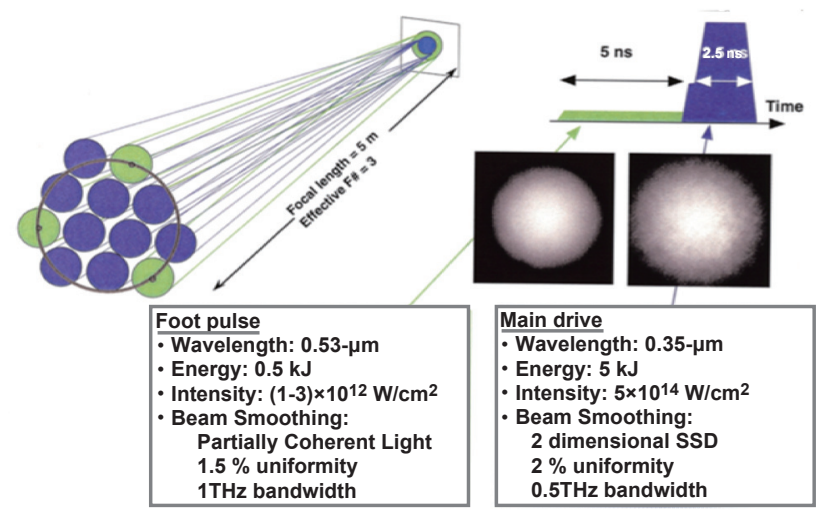

(a)
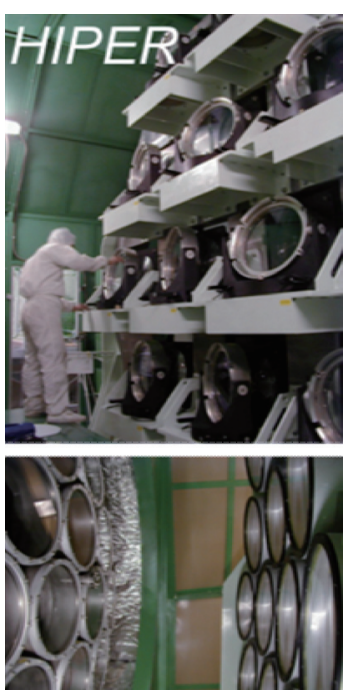

(b)

Fig. 4 HIPER irradiation system. (a) Multi-frequency bundle-irradiation configuration, (b) final turning mirrors and focusing lenses of the bundle irradiation system.

た ${ }^{18)}$ 。さらに，人為的にRT不安定性を抑制する手法と して, 輻射輸送 ${ }^{19)}$ や非局所電子熱伝導 ${ }^{20,21)}$ を取り入れる ことを提案し，それぞれの有効性が実証された。

$3.6 \mathrm{CPA} よ る$ 超短パルス超高強度レーザーと高速 点火核融合へのアプローチ

近年取り上げられている高速点火方式では, 高密度に 圧縮された燃料に外部から同期して短時間内に加熱工ネ ルギーを注入し，点火部を形成する，中心点火では，中 心スパークの半径と周りの主燃料の厚さがほぼ等しくな るのに対し，高速点火では中心スパーク部を作らなくて 良いため, 燃料は中実で等密(isochoric)である，従って 同じ主燃料 $\rho R$ であるなら, コアの半径は中心点火の半 分, 従って燃料の質量は約1桁小さくてすむ。 それに伴 い, 所要のレーザーエネルギーも約1桁小さくなるので, 炉設計の観点からは自由度が大きくなる。これは, 同じ $\rho R$ を保って燃料の質量を小さくするという慣性核融合 の原理に添うものであり, 高速点火がadvanced targetと して真に画期的なのはこの点においてである。

高密度に圧縮された燃料を瞬時に加熱する高速点火方 
式は，アイディア自体は非公式ながら1983年には存在し ていた ${ }^{22)}$ 。その後1985年にチャープパルス増幅 (CPA: Chirped Pulse Amplification) 技術が実現し ${ }^{23)}$, 超短パルス $(\sim 1 \mathrm{ps})$ でペタワット $\left(\mathrm{PW}=10^{15} \mathrm{~W}\right)$ オーダーの超高強度 レーザーが得られるようになり，2000年代に入ってはじ

めて高速点火の研究が現実的となった ${ }^{24)}$.

加熱エネルギー源としては, 超短パルス超高強度レー ザー照射により発生させた高エネルギー電子流が有力候 補である。すなわち, 高速点火の原理はビーム加熱であ り，大電流ビーム・プラズマ相互作用が物理機構とな る. 高速電子発生のレーザー波長依存性などの理由か

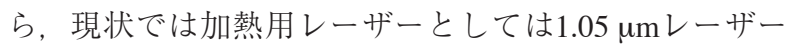
が主流に考えられているが，コアプラズマ周辺にはレー ザーのカットオフ密度よりはるかに高い密度のプラズマ が存在し, その中を出来るだけコアに近い位置までエネ ルギーを伝搬させる必要がある。この手法としては，ま ずレーザー・プラズマ相互作用の非線形性を利用して自 己収束モード的伝搬25)を行わせる方式が提案され，さら に新しい手法として，シェルターゲットに金属製のコー ンを設けることが提案されて実験に導入された。 大阪大 学では爆縮用の激光XII号レーザーに併設して1997年に $100 \mathrm{TW}(50 \mathrm{~J} / 0.5 \mathrm{ps}), 2001$ 年に $1 \mathrm{PW}(1 \mathrm{~kJ} / 1 \mathrm{ps})$ のビーム ラインが完成し, 日英の協力研究によりコーン付きシェ ルターゲットを用いて激光XII号により圧縮された燃料 プラズマを約 $1 \mathrm{keV}$ まで追加熱することに成功したと報 告され ${ }^{26)}$, これを機に高速点火核融合の研究が一気に活 発化した。

高速点火の統合実験は当初大阪大学のみで行われてい たが, advanced targetとしての重要性から, 米国OMEGA レーザーでも実験が開始され ${ }^{27)}$ ，NIFでも実験が検討さ れている。

\section{4. レーザー核融合研究の現状}

前述のような経過を経て, 現在はいよいよ核融合点火 を目指した研究が展開されている。我が国では直接照射 爆縮・高速点火方式を主眼としたFIREX計画が進行中で あり, 現在は核融合点火温度 $5 \mathrm{keV}$ ま゙の高速加熱を実 証すべく，新しいLFEXレーザーを建設して研究が展開 されている。米国においては，NIFにおいて間接照射爆 縮・中心点火方式で点火燃焼実現を目指した実験が進行 中である。フランスでは, NIFと同様のレーザー装置 LMJを米国から数年遅れで建設中である。これらの計画 が進んで点火燃焼が実証されれば，レーザー核融合炉実 現にむけた大きなステップを越えることになる。

\section{1 高速点火核融合の研究とFIREX計画}

コーン付きターゲットで先述のCDシェルのような高 密度爆縮ができ，これを5-10 keVまで加熱できれば, 点火・燃焼が既存技術で確実に達成できると考えられ る。この加熱原理実証を目標として大阪大学では核融合 科学研究所と連携し2003年よりFIREX-1計画をスタート し, $10 \mathrm{~kJ} / 1$ - $10 \mathrm{ps}$ の加熱用レーザーLFEX ${ }^{28)}$ (Fig. 5)を建

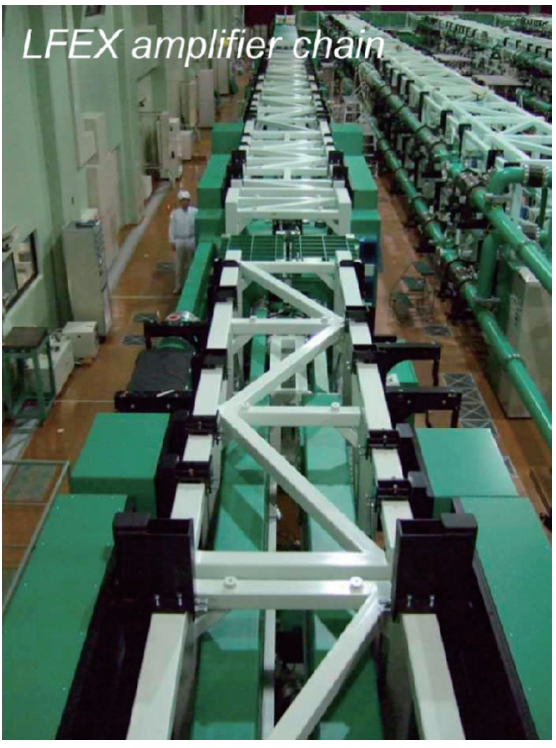

Fig. 5 Main amplifier of the LFEX laser.

設し，2009年より爆縮加熱統合実験を開始した ${ }^{29)}$ 。超高 強度レーザー照射時の硬X線過酷環境下でも正常動作す る様々なプラズマ診断技術の開発により，2010年には核 融合反応中性子数を高精度で測定し, 加熱による中性子 数の増大を再検証することに成功し，発生中性子数は 2002年の記録を更新した ${ }^{30)}$. 現在，加熱レーザーの出力

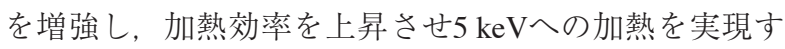
ベく，実験を展開している。

高速点火では，短パルス超高強度レーザーにより高速 電子流を発生し，これを爆縮コアに導いて加熱を行う. 相対論的電子の発生には様々な機構があるが, レーザー 強度が $10^{18} \mathrm{~W} / \mathrm{cm}^{2}$ 以上ではレーザーの電場で振動する電 子は相対論的になり，エネルギーはMeVオーダーとな る。またこのようなレーザー強度では，プラズマの屈折 率が相対論効果や電子密度変調によりレーザー強度に依 存する。そのような状況の中で, 相対論的大電流電子 ビームの輸送は強度の非線形性を示すことになり，その 物理機構は必ずしもよく解っているとは言えない. プラ ズマ物理としては興味深いが, ターゲット設計上はある 程度経験則に頼りながら進めざるを得ない状況である。

FIREX-1において5 keVの高速加熱が成功し，一方で NIFにおいて高密度圧縮燃料での燃焼が実現すれば，高 速点火方式でのレーザー核融合は実現性の高いものとな る。これらの成功を受けた高速点火方式による点火燃焼 計画としてFIREX-2が計画されている.

\section{2 米国NIFにおける点火燃焼実験の現状}

米国ローレンスリバモア研究所のNIFにおいて，間接 照射 · 中心点火方式で核融合点火燃焼の達成が目前に

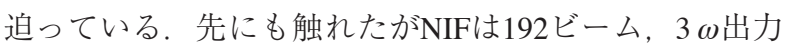
$1.8 \mathrm{MJ}$ の世界最大のレーザー装置で，2010年5月に建設 完成，稼働を開始し，2010年9月からクライオ燃料層を もつターゲットを用いた統合実験を開始した ${ }^{31)}$ 、レー ザー装置, クライオターゲット装置, プラズマ計測装置 は極めて順調に稼働している. 
2012年9月末までに点火を達成するのが彼らのNIC (National Ignition Campaign) 計画での目標だったが, 残 念ながら未だ点火には成功していない ${ }^{32}$. 解決すべき 4 つの物理課題 (1)アイセントロープ, (2)爆縮速度, (3)燃 料形状，(4)中心スパークと種燃料のミキシング)がある とされている。そのうち，(1)と(2)はほぼ解決している が, (3)と(4)についてはまだ制御しきれていないようであ る。これらはいずれも輻射流体の問題であるが, 計算 コードによる設計の精度が十分ではなかったことを意味 するため極めて重要である.

そうは言うものの，統合実験を始めてわずか 2 年，フ ル出力での実験が半年しかなかった中で, 実験は着実に 進行し点火に近づいている。達成された燃料パラメータ (括弧内は目標值) は, 主燃料密度 $\rho=600-800 \mathrm{~g} / \mathrm{cm}^{3}$ $\left(1200 \mathrm{~g} / \mathrm{cm}^{3}\right), \rho R=1.2-1.3 \mathrm{~g} / \mathrm{cm}^{2}\left(1.5 \mathrm{~g} / \mathrm{cm}^{2}\right)$, 中心又 パーク密度 $\rho=40-50 \mathrm{~g} / \mathrm{cm}^{3}\left(130 \mathrm{~g} / \mathrm{cm}^{3}\right), \rho R=0.1 \mathrm{~g} / \mathrm{cm}^{2}$ $\left(0.3 \mathrm{~g} / \mathrm{cm}^{2}\right)$ という素晴らしい成果である(主然料はほほ 実現したが, 中心点火スパークの密度があと2-3倍足り ない)。核融合反応で発生した $\alpha$ 粒子のエネルギーは中 心スパークの熱エネルギーの $2.5 \% に$ 達しており, 既に 中性子発生数の約 $15 \%$ が $\alpha$ 粒子加熱によるものと評価さ れている。

NIFを用いた研究は今後3年間延長されることが決 まっている。これは点火実験, 流体実験, 物質科学等か らなり, 点火実験も直接照射を含むものとされ, 一点設 計 (point design)への集中から多様性を追求する方針に切 り替えるとのことである.

\section{5. 今後の展望}

\section{1 レーザー核融合炉にむけて}

レーザー核融合炉としてどのようなデザインが可能 か. 我が国では, 高繰り返しレーザーとコーン付き燃料 の高速点火核融合を基本とした，固体壁または液体壁の 炉設計が進められており ${ }^{33)}$ ，FIREX-2の後に，200kJ/ $1 \mathrm{~Hz}$ のレーザーで2 MWの正味電気出力を得る実証炉 LIFT (Laser Inertial Fusion Test) (Fig. 6) 等を経て, $1 \mathrm{MJ} /$ $16 \mathrm{~Hz}$ のレーザーで600 - $1200 \mathrm{MW}$ 出力する商用プラン

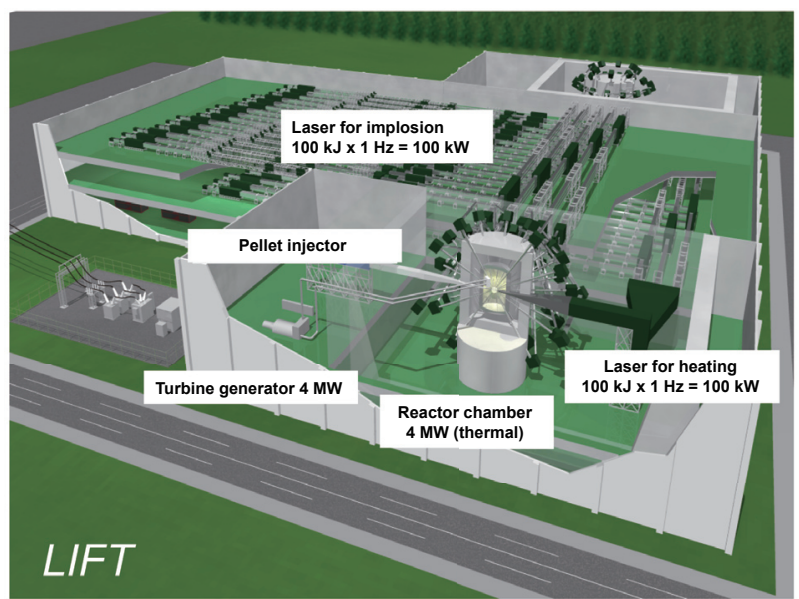

Fig. 6 Laser fusion experimental reactor LIFT (IFE Forum).

\section{トKOYO-Fastに至る}

レーザー核融合炉の大きなメリットのひとつに，炉お よび炉心プラズマとエネルギードライバーであるレー ザーを空間的に分離することが出来る点があげられる。 高価なドライバーは炉システムの問題から切り離すこと が出来る。また, ターゲット設計により, 炉心プラズマ にバリエーションを得やすいことも大きな特徴である.

米国では，NIFの点火燃焼を実現した後の計画として LIFE (Laser Inertial Fusion Engine) 計画が提案されてい る。これは，核融合/核分裂ハイブリッド炉を構成し， 核融合反応で生成される豊富な中性子を用いて炉壁部分 に装着した使用済み核分裂然料を照射し，さらなるエネ ルギー生成と核変換による消滅処理を同時に行うもので あり, 純粋な核融合炉より効率が高い( 純粋な核融合炬 のオプションもある)。核融合炉心プラズマとしては NIFターゲット設計を基準にし, 出力 $1 \mathrm{MJ}$ のレーザーを $15 \mathrm{~Hz}$ で照射, 熱出力3000 MWを発生し, 30年間連続運 転する．NIFの点火燃焼が成功すれば，その20年後には 発電炉が出来るとの果敢な提案である。

\section{2 レーザーに求められるもの}

おそらくもっとも大きな開発課題は, 大出力高ピーク パワーで高繰り返しのレーザー技術であろう。高速点火 核融合をべースとした先述のKOYO-Fastでのレーザーの 仕様は，爆縮用に効率13\%の $1.1 \mathrm{MJ} / 32$ ビーム，加熱用に 効率5.4\%の $100 \mathrm{~kJ} / 1$ ビームで， $16 \mathrm{~Hz}$ 動作となっている. 爆縮用レーザーのうちフットパルスはビーム平滑化のた め広帯域増幅を必要とするのでOPA（光パラメトリック 増幅)とし, 効率を要する主パルスは狭帯域動作とす る。加熱用レーザーも広帯域が必要なので, OPCPA (Optical Parametric Chirped Pulse Amplification)を採用す る.

レーザー核融合炉では，ドライバーレーザーはモ ジュール化が可能であり，1台で大出力のレーザーでな くても，ある程度の出力規模のモジュールさえ出来れば あとは台数を増やせばよいという容易さがある。そのよ うなレーザーの候補として, 冷却したYb:YAGをレー ザー媒質とする半導体レーザー励起個体レーザーの開発 が進められている ${ }^{34)}$

セラミックレーザー材料は高繰り返しに適し, 長寿 命, またYbは高出力半導体レーザーの発振波長とマッ チングがよく, 高効率, 低コスト化の可能性が高い. 七 ラミック材料技術の最近の進歩により，単結晶と同等の 材料が得られるようになってきた。励起用の高出力半導 体レーザーのコストダウンも大きな要因である。実際, レーザー核融合発電炉のコストのかなりの部分が半導体 レーザーによるものになると考えられ，他の産業との関 連や量産化が不可欠である。開発技術としては，高輝度 半導体レーザー, 大型セラミックス材料, 高平均出力光 学素子, 高破壊耐力光学薄膜, 低温冷却半導体レー ザー，など，多くの課題があり，着実な進展が望まれ る. 
6. まとめ

プラズマ物理からの要請がレーザーに革新技術を求 め, また逆に新しいレーザー技術がレーザー核融合研究 を飛躍的に推進し，さらに多方面への応用をもたらし た. 1960年のレーザー発明から50年を経てレーザー核融 合はいよいよ核融合点火燃焼実験を開始するに至り, そ れはおそらくあと数年内には達成されると期待される。 核融合点火燃焼は科学技術開発史上の大きな出来事とし て人々に記憶されることとなるであろう。 その時点で, 人類のエネルギー資源に関する認識は大きく変わるので はないだろうか.

核融合点火燃焼が達成されれば，レーザー核融合炉の 少なくとも炬心プラズマは実現したことになる。ドライ バーとしてはさらに高性能・高出力レーザーの開発が求 められるが, 早ければ2030年頃には磁場閉じ込めよりも 早くレーザー核融合発電プラントが実現しているかもし れない.

\section{謝 辞}

このたび，レーザー学会40周年を迎えるにあたり， レーザー核融合の進展と現状を概観する記念特別解説論 文を著す機会をいただきました学会誌「レーザー研究」編 集委員会に感謝申し上げます。

\section{参考文献}

1) T. H. Maiman: Nature 187 (1960) 493

2) G. Velarde and N. C. Santamari (ed.): Inertial Confinement Nuclear Fusion: A Historical Approach by Its Pioneers (Foxwell \& Davies, 2007).

3) J. Nuckolls, L. Wood, A. Thiessen, and G. Zimmerman: Nature 239 (1972) 139. (この内容は, E. Tellerにより「新式内燃機 関」として1972年5月のIQEC会議で報告され, その講演内容 はレーザー学会誌創刊号でも紹介された。レーザー研究, 1 (1973) 7.)

4) K. Estabrook and W. L. Kruer: Phys. Rev. Lett. 40 (1978) 42

5) C. Yamanaka, S. Nakai, T. Yabe, H. Nishimura, S. Uchida, Y. Izawa, T. Norimatsu, N. Miyanaga, A. Azechi, M. Nakai, et al.: Phys. Rev. Lett. 56 (1986) 1575; C. Yamanaka, K. Mima, S. Nakai, T. Yamanaka, Y. Izawa, Y. Kato, K. Nishihara, T. Mochizuki, M. Yamanaka, M. Nakatsuka, et al.: in Plasma Physics and Controlled Nuclear Fusion Research 1986, vol. 3 (1987) p. 33.

6) H. Takabe, M. Yamanaka, K. Mima, C. Yamanaka, H. Azechi, N. Miyanaga, M. Nakatsuka, T. Jitsuno, T. Norimatsu, M. Takagi, et al.: Phys. Fluids 31 (1988) 2884.

7) H. Azechi, T. Jitsuno, T. Kanabe, M. Katayama, K. Mima, N. Miyanaga, M. Nakai, S. Nakai, H. Nakaishi, M. Nakatsuka, et al.: Laser and Particle Beams 9 (1991) 193.

8) Y. Kato, K. Mima, N. Miyanaga, S. Arinaga, Y. Kitagawa, M. Nakatsuka, and C. Yamanaka: Phys. Rev. Lett. 53 (1984) 1057.

9) H. Takabe, K. Nishihara, K. Mima, S. Nakai, H. Sakagami, A. Nishiguchi, and C. Yamanaka: in Plasma Physics and Controlled Nuclear Fusion Research 1992, vol. 3 (1993) p. 143.

10) S. Skupsky, R. W. Short, T. Kessler, R. S. Craxton, S. Letzring, and J. Soures: J. Appl. Phys. 66 (1989) 3456.

11) N. Miyanaga, S. Matsuoka, A. Ando, K. Tsubakimoto, S. Amano, M. Nakatsuka, T. Kanabe, T. Jitsuno, S. Nakai: in Proc. First Annual International Conference on Solid State Lasers for Application to Inertial Confinement Fusion1995, SPIE Proc. Vol. 2633 (1995) 183

12) M. D. Cable, S. P. Hatchett, J. A. Caird, J. D. Kilkenny, H. N.
Kornblum, S. M. Lane, C. Laumann, R. A. Lerche, T. J. Murphy, J. Murray, et al:: Phys. Rev. Lett. 73 (1994) 2316.

13) F. J. Marshall, R. S. Craxton, J. A. Delettrez, D. H. Edgell, L. M. Elasky, R. Epstein, V. Yu. Glebov, V. N. Goncharov, D. R. Harding, R. Janezic, et al.: Phys. Plasmas 12 (2005) 056302.

14) L. Rayleigh: Proc. London Math. Soc. 14 (1882) 170; G. Taylor, Proc. R. Soc. London, Ser. A 201 (1950) 192.

15) H. Azechi, M. Nakai, K. Shigemori, N. Miyanaga, H. Shiraga, H. Nishimura, M. Honda, R. Ishizaki, J. G. Wouchuk, H. Takabe, et al.: Phys. Plasmas 4 (1997) 4079.

16) S. Bodner: Phys. Rev. Lett. 33 (1974) 761; H. Takabe, K. Mima, L Montierth, and R. L. Morse: Phys. Fluids 28 (1985) 3676; R. Betti, V. N. Goncharov, R. L. McCrory, and C. P. Verdon: Phys. Plasmas 5 (1998) 1466.

17) H. Azechi, T. Sakaiya, S. Fujioka, Y. Tamari, K. Otani, K. Shigemori, M. Nakai, H. Shiraga, N. Miyanaga, and K. Mima: Phys. Rev. Lett. 98 (2007) 045002.

18) T. Sakaiya, H. Azechi, M. Matsuoka, N. Izumi, M. Nakai, K. Shigemori, H. Shiraga, A. Sunahara, H. Takabe, and T. Yamanaka: Phys. Rev. Lett. 88 (2002) 145003.

19) S. Fujioka, A. Sunahara, K. Nishihara, N. Ohnishi, T. Johzaki, H. Shiraga, K. Shigemori, M. Nakai, T. Ikegawa, M. Murakami, et al.: Phys. Rev. Lett. 92 (2004) 195001.

20) K. Shigemori, H. Azechi, M. Nakai, M. Honda, K. Meguro, N. Miyanaga, H. Takabe, and K. Mima: Phys. Rev. Lett. 78 (1997) 250; Phys. Rev. Lett. 80 (1998) 3415.

21) K. Otani, K. Shigemori, T. Sakaiya, S. Fujioka, A. Sunahara, M. Nakai, H. Shiraga, H. Azechi, and K. Mima: Phys. Plasmas 14 (2007) 122702.

22）山中 龍彦：金剛計画（第1期）検討作業報告書別冊（1983） p.5 (unpublished).

23) D. Strickland and G. Mourou: Opt. Commun. 56 (1985) 219.

24) N. G. Basov, S. Yu. Gus'kov, and L. P. Feokistov: J. Soviet Laser Research 13 (1992) 396; M. Tabak, J. Hammer, M. E. Glinsky, W. L. Kruer, S. C. Wilks, J. Woodworth, E. M. Campbell, M. D. Perry, and R. J. Mason: Phys. Plasmas 1 (1996) 1626.

25) K. A. Tanaka, R. Kodama, H. Fujita, M. Heya, N. Izumi, Y. Kato, Y. Kitagawa, K. Mima, N. Miyanaga, T. Norimatsu, et al.: Phys. Plasmas 7 (2000) 2014; R. Kodama, K. Mima, K. A. Tanaka, Y. Kitagawa, H. Fujita, K. Takahashi, A. Sunahara, K. Fujita, H. Habara, T. Jitsuno, et al.: Phys. Plasmas 8 (2001) 2268; Y. Kitagawa, Y. Sentoku, S. Akamatsu, W. Sakamoto, K. A. Tanaka, R. Kodama, H. Nishimura, Y. Inubushi, M. Nakai, T. Watari, et al.: Phys. Rev. E 71 (2005) 016403.

26) R. Kodama, P. A. Norreys, K. Mima, A. E. Dangor, R. G. Evance, H. Fujita, Y. Kitagawa, K. Kurshelnick, T. Miyakoshi, N. Miyanaga, et al.: Nature 412 (2001) 798; R. Kodama, H. Shiraga, K. Shigemori, Y. Toyama, S. Fujioka, H. Azechi, H. Fujita, H. Habara, T. Hall, Y. Izawa, et al.: Nature 418 (2002) 933.

27) W. Theobald, A. A. Solodov, C. Stoeckl, K. S. Anderson, R. Betti, T. R. Boehly, R. S. Craxton, J. A. Delettrez, C. Dorrer, J. A. Frenje, et al.: Phys Plasmas 18 (2011) 056305.

28) N. Miyanaga, H. Azechi, K.A. Tanaka, T. Kanabe, T. Jitsuno, J. Kawanaka, Y. Fujimoto, R. Kodama, H. Shiraga, K. Knodo, et al.: EDP Sciences, J. de Physique IV 133 (2006) 81.

29) H. Azechi, K. Mima, y. Fujimoto, S. Fujioka, H. Homma, M. Isobe, A. Iwamoto, T. Jitsuno, T. Johzaki, R. Kodama, et al.: Nuclear Fusion 49 (2009) 104024.

30) H. Shiraga, S. Fujioka, M. Nakai, T. Watari, H. Nakamura, Y. Arikawa, H. Hosoda, T. Nagai, M. Koga, H. Kikuchi, et al.: High Energy Density Physics 8 (2012) 227; H. Shiraga, S. Fujioka, M. Nakai, T. Watari, H. Nakamura, Y. Arikawa, H. Hosoda, T. Nagai, M. Koga, H. Kikuchi, et al.: Plasma Phys. Control. Fusion 53 (2011) 124029.

31) J. Lindl: in Proc. $23^{\text {rd }}$ IAEA Fusion Energy Conference, Daejeon, Korea, 11-16 October, 2010.

32) E. Moses: to be published in Proc. $24^{\text {th }}$ IAEA Fusion Energy Conference, San Diego, 2012.

33）レーザー核融合炉設計委員会報告書「高速点火レーザー核 融合炬発電プラントの概念設計」, 大阪大学レーザーエネ ルギー学研究センター/IFEフォーラム・レーザー核融合技 術振興会 (2006).

34）宮永憲明, 河仲準二, 川嶋利行, 椿本孝治, 藤本靖, 久保村浩之, 松岡伸一, 池川恭史, 鈴木良和, 土屋昇, 他：プラズマ・核融合学会誌 83 (2007) 3. 